\title{
ANALYSIS OF THE CHEMICAL ATTRIBUTES OF A TYPIC HAPLUDULT SOIL UNDER FOREST SYSTEMS
}

\author{
David Silva Gomes ${ }^{1}$, Cláudio Roberto Marciano ${ }^{1}$, Lucas Luís Faustino ${ }^{1 *}$ \\ ${ }^{1}$ Universidade Estadual do Norte Fluminense Darcy Ribeiro, Laboratório de Solos - Campos dos Goytacazes - RJ - Brazil \\ david_gomes15@hotmail.com,marciano@uenf.br, lucas.faustino@uenf.br* \\ Received for publication: 08/10/2019 - Accepted for publication: 21/04/2020
}

\begin{abstract}
Resumo
Análise dos atributos químicos de um Argissolo Vermelho-Amarelo típico sob sistemas florestais. O presente estudo teve como objetivo avaliar a qualidade química de um Argissolo Vermelho-Amarelo Distrófico sob capoeira, leguminosas arbóreas e pastagem, no Município de Conceição de Macabú, RJ, implantadas em dezembro de 1998. Em julho de 2015, amostras de solo das camadas 0-0,10 m e 0,100,20 $\mathrm{m}$ foram coletadas e analisadas. O teor de $\mathrm{C}$ na camada $0-0,10 \mathrm{~m}$ foi maior na capoeira e menor no pasto. Os valores de CTCefet, $\mathrm{CTCpH}=7$ e teores de $\mathrm{N}, \mathrm{P}, \mathrm{Ca}, \mathrm{Mg}$ e $\mathrm{K}$ foram menores no pasto, maiores na acácia ou capoeira e intermediários no ingá e sabiá. Quanto às coberturas vegetais, essas variáveis químicas tiveram, de modo geral, os menores valores no pasto, os maiores na acácia ou na capoeira, e os intermediários no ingá e sabiá. Concluiu se que a revegetação leva a modificações na camada superficial do solo que tornam seus atributos próximos aos da capoeira e afastados dos da pastagem, indicando aumento da qualidade para dar suporte ao funcionamento de um ecossistema florestal, a despeito da piora de alguns indicadores da qualidade agronômica.

Palavras-chave: matéria orgânica do solo, leguminosa arbórea, fertilidade do solo, recuperação de área degradada.
\end{abstract}

\begin{abstract}
The aim of this study was to evaluate the chemical quality of a Typic Hapludult soil under secondary forest (capoeira), pasture and three leguminous tree species: Acacia auriculiformis, Mimosa caesalpiniaefolia and Inga edulis, in Conceição de Macabú County, Rio de Janeiro State, Brazil, implemented in December 1998. Soil samples from the $0-0.10$ and 0.10-0.20 m layers were collected and analyzed in July/2015. The C content in the $0.10 \mathrm{~m}$ layer was higher in capoeira and lower in the pasture. The $\mathrm{CEC}_{\mathrm{ef}}$ and $\mathrm{CEC}_{\mathrm{pH}=7}$ values and the $\mathrm{N}$, $\mathrm{P}, \mathrm{Ca}, \mathrm{Mg}$ and $\mathrm{K}$ levels were lower in pasture, higher in Acacia auriculiformis or capoeira, and intermediate in Inga edulis and Mimosa caesalpiniaefolia. The chemical variables regarding the vegetation cover generally had the lowest values in the pasture, the highest in the Acacia auriculiformis or capoeira, and intermediate values in Inga edulis and Mimosa caesalpiniaefolia. It was concluded that revegetation leads to changes in the superficial layer of the soil which make its attributes closer to those of capoeira and further away from those of pasture, indicating an increase in quality to support the functioning of a forest ecosystem, despite the worsening of some Agronomic quality indicators.

Keywords: degraded area revegetation, soil fertility, soil organic matter, leguminous tree.
\end{abstract}

\section{INTRODUCTION}

Soils in Brazil are mostly highly weathered, with kaolinitic or oxidic mineralogy, presenting little nutrient reserves and low cation exchange capacity, evidencing reduced chemical quality. These aspects give organic matter a central role in determining the quality of these soils, mainly regarding the chemical aspect, because in addition to controlling the availability of usually anionic nutrients (N, P and S, among the macronutrients), organic matter is also responsible for most of the to soil's cation exchange capacity (RAIJ, 1969; VEZZANI et al., 2008), which directly depends on the availability of other macronutrients ( $\mathrm{Ca}, \mathrm{Mg}$ and $\mathrm{K}$ ).

Farming generally causes soil degradation, especially in tropical countries. Soil degradation in the North Fluminense region was a consequence of cutting and burning forests and a long monocultivation period of coffee and sugar cane, intensive mechanization and fire use in pastures (GAMA-RODRIGUES et al., 2008; GOMES et al., 2018).

Implanting forest systems with leguminous tree species is one of the most used strategies to recover degraded areas, because it improves the fertility (by biological fixation of $\mathrm{N}_{2}$ and nutrient cycling), increases the organic matter content and biological activity, and improves physical attributes (GAMA-RODRIGUES et al., 2008; MACEDO et al., 2008; GOMES et al., 2018).

Soil quality is directly related to its functionality in managed or natural ecosystems, highlighting the ability to sustain biological activity, maintain environmental quality and provide the growth and health of plants and animals (CUNHA NETO et al., 2018). According to Bonini et al. (2015), the soil is a complex environment where many chemical, physical and biological processes interact which are in constant flux, and are heterogeneous

FLORESTA, Curitiba, PR, v. 51, n. 2, p. 447-456, abril/jun 2021

Gomes, D. S. et.al.

ISSN eletrônico 1982-4688

DOI: $10.5380 /$ rf.v51 i2. 69591 
in nature and often difficult to measure. Therefore, it follows the understanding that quality assessment should be done within the natural boundaries of each soil and environment.

The soil attributes from which inferences can be made about their quality are called soil quality indicators, and may be of various natures (biological, mineralogical, among others). Factors of a chemical nature can positively or negatively influence plant growth, however it is difficult to classify them or separate them because they are intimately related and interact with each other. Meurer (2007) highlights those related to: (a) the soil mineralogical composition; (b) nutrient availability; (c) the presence of toxic elements; (d) the presence of heavy metals; (e) the organic matter content; (f) sorption, precipitation, reduction and oxidation reactions; and (g) salinity. In this context, cation exchange capacity (CEC) is of prominent importance as a soil quality indicator because it indicates the amount of positive ions that a soil is capable of retaining, with its quantity being closely related to the soil $\mathrm{pH}$ and the quantity and nature of the charge-generating colloidal particles (clay and organic matter).

The present study was based on the hypothesis that areas revegetated with leguminous trees determine better chemical conditions in the soil when compared to pastures (degraded areas), and that they tend to approach the areas under forest over the years. In view of the above, the objective of this study was to evaluate the efficiency of revegetating areas with leguminous forest species to recover the chemical quality of a Typic Hapludult soil under secondary forest (popularly known in Brazil as capoeira), leguminous tree species and pasture on a hillside in the Municipality of Conceição de Macabú, RJ, Brazil.

\section{MATERIAL AND METHODS}

The study area is located in the municipality of Conceição de Macabú, North of Rio de Janeiro, at Carrapeta Farm $\left(21^{\circ} 37^{\prime} \mathrm{S}\right.$ and $\left.42^{\circ} 05^{\prime} \mathrm{W}\right)$. The region's climate is Am type according to the Köppen classification, being hot and humid with an average temperature of $26^{\circ} \mathrm{C}$ and an average annual rainfall of $1400 \mathrm{~m}$ (GAMARODRIGUES et al., 2008). The relief is strong wavy, with a slope around $0.35 \mathrm{~m} \mathrm{~m}^{-1}$. The soil is an Argissolo Vermelho-Amarelo Distrófico according to the Brazilian Soil Classification System (SANTOS et al., 2018), or a Typic Hapludult soil according to the American Soil Classification System (SOIL SURVEY STAFF, 2014).

Thus, five areas under different vegetation covers were studied in the aforementioned site. Three of these areas consist of pure plantations of the leguminous trees Acacia auriculiformis, Mimosa Caesalpiniifolia and Inga edulis species. The planting was carried out in December 1998 for the purposes of environmental recovery in plots of $1500 \mathrm{~m}^{2}(75 \mathrm{~m} \times 20 \mathrm{~m})$. The species were inoculated with selected atmospheric $\mathrm{N}_{2}$ fixating bacteria strains (BR 3465 and BR 3609 for Acacia auriculiformis and BR 3407 and 3446 for Mimosa Caesalpiniifolia) and mycorrhizal fungi (a combination of Gigaspora Margarita and Glomus Clarum for all leguminous species). Seedlings of the tree species were $30 \mathrm{~cm}$ height, and with great nodulation and mycorrrization for the leguminous species (good seedling growth and presence of active nodules). In addition, 3 x 2 m spacing was implemented and $150 \mathrm{~g}$ of simple superphosphate and $10 \mathrm{~g}$ of potassium chloride were added into pits of $0.20 \times 0.20 \times 0.20 \mathrm{~m}$.

The other two areas adjacent to the leguminous plantations have a pasture and a capoeira as vegetation covers. The pasture represents the vegetation preceding the planting of tree species, and dates back to the 1930s when there was suppression of coffee cultivation. It has a predominance of molasses grass (Melinis minutiflora), Pernambuco grass (Paspalum maritimum) and satintails grass (Imperata brasiliensis), being admitted as a degraded area reference because it has little or no soil cover. The capoeira is a forest fragment of Atlantic forest in secondary succession with species at different successional stages. It has been growing for 50 years without tree removal by anthropic action and was admitted as a preserved area reference (GAMA-RODRIGUES et al., 2008) (Figure 1).

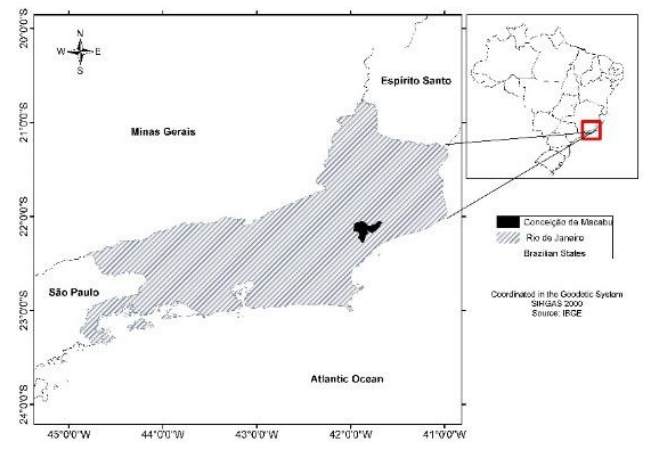

Figure 1. Location of the experiment

Figura 1. Localização da área experimental

FLORESTA, Curitiba, PR, v. 51, n. 2, p. 447-456, abril/jun 2021.

Gomes, D. S. et.al.

ISSN eletrônico 1982-4688

DOI: $10.5380 /$ rf.v51 i2. 69591 
The choice of capoeira as one of the reference ecosystems is one of the strategies used to evaluate soil alterations due to different land uses and management techniques, as it allows to compare of soil characteristics managed with those of the unmanaged soil under natural vegetation (COSTA et al., 2014; FAUSTINO et al., 2020).

Samples were collected in July 2015 in each plot in the layers $0-0.10 \mathrm{~m}$ and $0.10-0.20 \mathrm{~m}$ deep with deformed and undisturbed structure from six points (repetitions) in each area. The deformed air-dried samples were used for the granulometric analysis and chemical characterization according to the methods described in EMBRAPA (2017).

Organic carbon was determined with potassium dichromato by colorimetry using the method described by Anderson and Ingram (1993). Other chemical attributes were determined according to the analytical methods presented in EMBRAPA (2017), briefly described below: total nitrogen, determined by the Kjeldahl method by diffusion camera; $\mathrm{pH}$ in water, determined by potentiometry in soil-water solution, at a proportion of 1:2.5; Available phosphorus, extracted with Mehlich $^{-1}$ solution and determined by atomic absorption spectrophotometry; exchangeable aluminum, extracted with a $\mathrm{KCl} 1 \mathrm{~mol} \mathrm{~L}^{-1}$ solution in the soil-solution proportion of 1:10, and determined by titration with $\mathrm{NaOH} 0.025 \mathrm{~mol} \mathrm{~L}^{-1}$ using bromothymol blue blue as an indicator; $\mathrm{H}+\mathrm{Al}$, extracted with $0.5 \mathrm{~mol} \mathrm{~L}^{-1}$ calcium acetate solution buffered at $\mathrm{pH}=7.0$, and determined by titration with $\mathrm{NaOH} 0.025 \mathrm{~mol}$ $\mathrm{L}^{-1}$ using phenolphthalein as an indicator; exchangeable calcium and magnesium extracted with $\mathrm{KCl} 1 \mathrm{~mol} \mathrm{\textrm {L } ^ { - 1 }}$ solution and determined by atomic absorption spectrophotometry; and exchangeable potassium and sodium extracted by Mehlich $^{-1}$ extractor and determined by flame photometry.

In addition to the $\mathrm{pH}$ and $\mathrm{C}$ contents and other elements mentioned above, the values of effective cation exchange capacity and $\mathrm{pH}=7.0\left(\mathrm{CEC}_{\mathrm{ef}}\right.$ and $\mathrm{CEC}_{\mathrm{pH}=7.0}$, respectively $)$, the sum of bases $\left(\mathrm{SB}=\mathrm{Ca}^{2+}+\mathrm{Mg}^{2+}+\mathrm{K}^{+}+\right.$

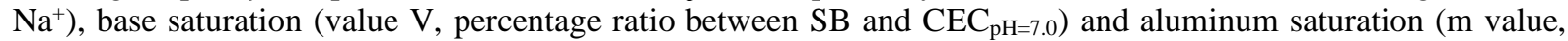
percentage ratio between $\mathrm{Al}$ and $\mathrm{CEC}_{\mathrm{ef}}$ ) were also calculated from the equation described in EMBRAPA (2017).

Undisturbed samples collected in $100 \mathrm{~mL}$ metal rings were used by Gomes et al. (2018) to determine the bulk density (BD), total porosity (TP), macroporosity (macro) and microporosity (micro), according to EMBRAPA (2017) (Table 1).

Table 1. Granulometric composition (sand, silt and clay contents), bulk density (BD), total porosity (TP), macroporosity (Macro) and microporosity (Micro) of a Typic Hapludult soil under different vegetation cover in the 0-0.10 m, 0.10-0.20 m and 0-0.20 m (average) layers in Conceição de Macabú, RJ, Brazil.

Tabela 1. Composição granulométrica (teores de areia, silte e argila), densidade (Ds), porosidade total (PT), macroporosidade (Macro) e microporosidade (Micro) de um Argissolo Vermelho-Amarelo sob diferentes coberturas vegetais $(*)$, nas camadas de profundidade 0-0,10 m, 0,10-0,20 m em Conceição de Macabu, RJ.

\begin{tabular}{|c|c|c|c|c|c|c|c|}
\hline \multirow{2}{*}{$\begin{array}{l}\text { Coverage } \\
\text { Vegetable }\end{array}$} & Sand & Silte & Clay & $\mathrm{BD}$ & PT & Macro & Micro \\
\hline & \multicolumn{3}{|c|}{ 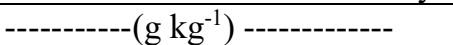 } & $\mathrm{Mg} \mathrm{m}^{-3}$ & \multicolumn{3}{|c|}{ - - } \\
\hline \multicolumn{8}{|c|}{ Layer $0-0.10 \mathrm{~m}$} \\
\hline \multirow{5}{*}{$\begin{array}{l}\text { Capoeira } \\
\text { Pasture } \\
\text { Acacia } \\
\text { auriculiformis } \\
\text { Inga edulis } \\
\text { Mimosa } \\
\text { caesalpinifolia }\end{array}$} & 640.0 & 85.5 & 274.5 & 1.114 & 0.580 & 0.398 & 0.181 \\
\hline & 637.6 & 90.7 & 271.7 & 1.361 & 0.486 & 0.223 & 0.263 \\
\hline & 627.1 & 70.1 & 302.8 & 1.386 & 0.477 & 0.249 & 0.228 \\
\hline & 610.8 & 93.1 & 296.1 & 1.215 & 0.542 & 0.321 & 0.221 \\
\hline & 603.8 & 96.8 & 299.4 & 1.258 & 0.525 & 0.294 & 0.233 \\
\hline \multicolumn{8}{|c|}{ Layer $0.10-0.20 \mathrm{~m}$} \\
\hline Capoeira & 598.6 & 93.8 & 307.6 & 1.093 & 0.587 & 0.355 & 0.233 \\
\hline Pasture & 533.3 & 110.2 & 356.5 & 1.271 & 0.520 & 0.265 & 0.255 \\
\hline $\begin{array}{l}\text { Acacia } \\
\text { auriculiformis }\end{array}$ & 510.0 & 96.0 & 394.0 & 1.474 & 0.444 & 0.175 & 0.268 \\
\hline Inga edulis & 535.7 & 108.3 & 356.0 & 1.283 & 0.516 & 0.241 & 0.275 \\
\hline $\begin{array}{l}\text { Mimosa } \\
\text { caesalpinifolia }\end{array}$ & 515.4 & 111.7 & 372.9 & 1.370 & 0.483 & 0.193 & 0.290 \\
\hline
\end{tabular}

BD: Bulk density, TP: total porosity, Macro: macropores diameter $\geq 50 \mu \mathrm{m}$ and Micro: Micropore diameter $\leq 50 \mu \mathrm{m}$. Analyses performed according to the Manual of Methods of Soil Analysis (EMBRAPA, 2017).

A statistical analysis of the results of the two layers which comprise the superficial horizon A was performed by admitting a completely randomized design, being similar to other studies carried out in the present study area (COSTA et al., 2014; GOMES et al., 2018; FAUSTINO et al., 2020). The treatments for the statistical

FLORESTA, Curitiba, PR, v. 51, n. 2, p. 447-456, abril/jun 2021.

Gomes, D. S. et.al.

ISSN eletrônico 1982-4688 
analysis were also considered in a split-plot scheme with the plant covers as plots, the two soil sampling layers as subplots, and the collection points as repetitions. The statistical analysis was performed using the Assistat program including the experimental variance analysis and a comparison of the means by the Tukey test at 5\% probability.

A principal component analysis (PCA) was subsequently performed for each Horizon A layer using the R 3.2.1 program (R Core Team, 2015) and the Vegan package (OKSANEN et al., 2016). The PCA was aimed at evaluating the dispersion of the five plant covers studied based on variables related to fertility $(\mathrm{pH}, \mathrm{C}, \mathrm{N}, \mathrm{P}, \mathrm{SB}$, $\mathrm{CTE}_{\mathrm{ef}}, \mathrm{CTE}_{\mathrm{pH}=7}, \mathrm{~V}$ and $\mathrm{M}$ ). The variables representative of these aspects were selected by the effective ability to distinguish the plant cover (identified from ANOVA and the Tukey Test), and at the same time not producing redundant information (identified by high correlations or causal relationships among the variables). Furthermore, a grouping analysis was performed for each layer using the Tocher method, which enables evaluating the similarity or dissimilarity of the inter and intra-group plant covers and the importance of each variable in the total variation available between the GENES statistical program (CRUZ et al., 2004).

\section{RESULTS}

The carbon content $(\mathrm{C})$ in the soil ranged from 13.1 to $18.8 \mathrm{~g} \mathrm{~kg}^{-1}$ in the $0-0.10 \mathrm{~m}$ layer, and between 10.8 and $12.2 \mathrm{~g} \mathrm{~kg}^{-1}$ in the $0.10-0.20 \mathrm{~m}$ layer. The highest $\mathrm{C}$ value occurred in the capoeira for the $0-0.10 \mathrm{~m}$ layer, not statistically differing from the area under Mimosa caesalpinifolia, but superior to the areas under Acacia auriculiformis, Inga edulis and pasture, while the $\mathrm{C}$ levels did not differ between the vegetation covers for the 0.10-0.20 m layer. The 0-0.10 m layer was superior to the $0.10-0.20 \mathrm{~m}$ layer for all plant coverings, except for pasture (Table 2).

Table 2. Chemical soil attributes of a Typic Hapludult soil under different vegetation covers in the 0-0.10 m, 0.10$0.20 \mathrm{~m}$ and 0-0.20 m (mean) layers in Conceição de Macabú, RJ, Brazil. pH, C, N, C/N ratio, P, Al, H $+\mathrm{Al}, \mathrm{Ca}$.

Tabela 2. Atributos químicos do solo sob diferentes coberturas vegetais, nas camadas de profundidade $0-0,10 \mathrm{~m}$, 0,10-0,20 m e 0-0,20 m (média), em um Argissolo Vermelho-Amarelo, em Conceição de Macabu, RJ: $\mathrm{pH}, \mathrm{C}, \mathrm{N}$, relação $\mathrm{C} / \mathrm{N}, \mathrm{P}, \mathrm{Al}, \mathrm{H}+\mathrm{Al}, \mathrm{Ca}$.

\begin{tabular}{|c|c|c|c|c|c|c|c|c|}
\hline \multirow[t]{2}{*}{$\begin{array}{l}\text { Coverage } \\
\text { Vegetable }\end{array}$} & $\begin{array}{c}\mathrm{pH} \\
\left(\mathrm{H}_{2} \mathrm{O}\right)\end{array}$ & \multicolumn{2}{|c|}{-------( $\left(\mathrm{g} \mathrm{kg}^{-1}\right)$------- } & \multicolumn{2}{|l|}{$\left(\underset{1}{\left(\mathrm{mg} \mathrm{kg}^{-}\right.}\right.$} & \multicolumn{3}{|c|}{-------( $\left.\mathrm{cmol}_{\mathrm{c}} \mathrm{kg}^{-1}\right)$------- } \\
\hline & & & & Layer & $0.10 \mathrm{~m}$ & & & \\
\hline Capoeira & $4.22 \mathrm{~b}$ & $18.8 \mathrm{aA}$ & $1.56 \mathrm{aA}$ & $1.83 \mathrm{a}$ & $12.0 \mathrm{a}$ & $1.13 \mathrm{aA}$ & $7.82 \mathrm{aA}$ & $0.39 \mathrm{bcA}$ \\
\hline Pasture & $\begin{array}{l}4.26 \\
\mathrm{ab}\end{array}$ & $13.1 \mathrm{bA}$ & $0.93 \mathrm{cA}$ & $3.35 \mathrm{a}$ & $14.9 \mathrm{a}$ & $0.85 \mathrm{aA}$ & $6.40 \mathrm{bA}$ & $0.24 \mathrm{cA}$ \\
\hline $\begin{array}{l}\text { Acacia } \\
\text { auriculiformis }\end{array}$ & $4.48 \mathrm{a}$ & $14.6 \mathrm{bA}$ & $1.37 \mathrm{abA}$ & $2.55 \mathrm{a}$ & $10.7 \mathrm{a}$ & $0.37 \mathrm{bA}$ & $6.77 \mathrm{bA}$ & $1.60 \mathrm{aA}$ \\
\hline Inga edulis & $\begin{array}{l}4.22 \\
\mathrm{ab}\end{array}$ & $13.9 \mathrm{bA}$ & $1.07 \mathrm{bcA}$ & $2.18 \mathrm{a}$ & $13.7 \mathrm{a}$ & $0.98 \mathrm{aA}$ & $6.55 \mathrm{bA}$ & $0.49 \mathrm{bcA}$ \\
\hline $\begin{array}{l}\text { Mimosa } \\
\text { caesalpinifolia }\end{array}$ & $\begin{array}{c}4.26 \\
\mathrm{ab} \\
\end{array}$ & $16.0 \mathrm{abA}$ & $1.36 \mathrm{abA}$ & $2.63 \mathrm{a}$ & $11.9 \mathrm{a}$ & $1.17 \mathrm{aA}$ & $7.77 \mathrm{aA}$ & $0.67 \mathrm{bA}$ \\
\hline Average & $4.29 \mathrm{~A}$ & 15.3 & 1.26 & $2.50 \mathrm{~A}$ & $12.6 \mathrm{~A}$ & 0.90 & 7.06 & 0.68 \\
\hline Capoeira & $4.12 \mathrm{~b}$ & $12.2 \mathrm{aB}$ & $1.10 \mathrm{aB}$ & $\begin{array}{c}\text { Layer } 0 \\
1.18 \mathrm{a}\end{array}$ & $\begin{array}{l}0-0,20 \mathrm{~m} \\
11.1 \mathrm{a}\end{array}$ & $1.12 \mathrm{aA}$ & $7.48 \mathrm{aA}$ & $0.12 \mathrm{bB}$ \\
\hline Pasture & $\begin{array}{c}4.18 \\
\mathrm{ab}\end{array}$ & $11.3 \mathrm{aA}$ & $0.86 \mathrm{aA}$ & $0.63 \mathrm{a}$ & $13.0 \mathrm{a}$ & $0.92 \mathrm{aA}$ & $7.07 \mathrm{aA}$ & $0.11 \mathrm{bA}$ \\
\hline $\begin{array}{l}\text { Acacia } \\
\text { auriculiformis }\end{array}$ & $4.34 \mathrm{a}$ & $11.1 \mathrm{aB}$ & $1.00 \mathrm{aB}$ & $1.63 \mathrm{a}$ & $11.3 \mathrm{a}$ & $0.88 \mathrm{aA}$ & $6.62 \mathrm{aA}$ & $0.53 \mathrm{aB}$ \\
\hline Inga edulis & $\begin{array}{c}4.28 \\
\mathrm{ab}\end{array}$ & $10.8 \mathrm{aB}$ & $1.01 \mathrm{aA}$ & $1.25 \mathrm{a}$ & $11.3 \mathrm{a}$ & $1.08 \mathrm{aA}$ & $6.57 \mathrm{aA}$ & $0.14 \mathrm{abB}$ \\
\hline $\begin{array}{l}\text { Mimosa } \\
\text { caesalpinifolia }\end{array}$ & $\begin{array}{c}4.22 \\
\mathrm{ab}\end{array}$ & $11.9 \mathrm{aB}$ & $1.00 \mathrm{aB}$ & $1.43 \mathrm{a}$ & $12.9 \mathrm{a}$ & $1.23 \mathrm{aA}$ & $6.65 \mathrm{aB}$ & $0.25 \mathrm{abB}$ \\
\hline Average & $4.22 \mathrm{~B}$ & 11.4 & 0.99 & $1.22 \mathrm{~B}$ & $11.9 \mathrm{~A}$ & 1.05 & 6.88 & 0.23 \\
\hline $\mathrm{CV}(\%)$ & 4.27 & 15.21 & 20.75 & 88.25 & 24.73 & 29.34 & 9.05 & 63.99 \\
\hline
\end{tabular}

For each column (meaning for each soil attribute), means followed by the same uppercase letter (comparing the layers) or the same lowercase letter (comparing the covers) do not differ from each other by the Tukey test at $5 \%$ probability.

Continuation Table 2.

FLORESTA, Curitiba, PR, v. 51, n. 2, p. 447-456, abril/jun 2021.

Gomes, D. S. et.al.

ISSN eletrônico 1982-4688 
Table 2. Chemical soil attributes of a Typic Hapludult soil under different vegetation covers in the 0-0.10 m, 0.10$0.20 \mathrm{~m}$ and 0-0.20 m (mean) layers in Conceição de Macabú, RJ, Brazil. Mg, K, Na, sum of bases (SB), effective cation exchange capacity $\left(\mathrm{CEC}_{\mathrm{ef}}\right)$ and the $\mathrm{pH}=7\left(\mathrm{CEC}_{\mathrm{pH}=7}\right)$, base saturation (value $\left.\mathrm{V}\right)$ and $\mathrm{Al}$ (m value).

Tabela 2. Atributos químicos do solo sob diferentes coberturas vegetais, nas camadas de profundidade $0-0,10 \mathrm{~m}$, 0,10-0,20 m e 0-0,20 m (média), em um Argissolo Vermelho-Amarelo, em Conceição de Macabu, RJ: $\mathrm{Mg}, \mathrm{K}, \mathrm{Na}$, soma de bases (SB), capacidade de troca de cátions efetiva (CTCefet) e a pH=7 (CTCpH=7), saturação por bases (valor V) e por $\mathrm{Al}$ (valor $\mathrm{m}$ ).

\begin{tabular}{|c|c|c|c|c|c|c|c|c|}
\hline $\begin{array}{l}\text { Coverage } \\
\text { Vegetable }\end{array}$ & $\mathrm{Mg}$ & $\mathrm{K}$ & $\begin{array}{c}\mathrm{Na} \\
\left.\mathrm{mol}_{\mathrm{c}} \mathrm{kg}^{-1}\right)-\end{array}$ & SB & $\mathrm{CEC}_{\mathrm{ef}}$ & $\mathrm{CEC}_{\mathrm{pH}=7}$ & \multicolumn{2}{|c|}{----(\%)---- } \\
\hline & \multicolumn{8}{|c|}{ Camada $0-0,10 \mathrm{~m}$} \\
\hline Capoeira & $0.38 \mathrm{abA}$ & $0.010 \mathrm{bc}$ & $0.007 \mathrm{a}$ & $0.79 \mathrm{bcA}$ & $1.9 \mathrm{a}$ & $8.6 \mathrm{abA}$ & $9.0 \mathrm{bcA}$ & $58.8 \mathrm{abB}$ \\
\hline Pasture & $0.15 \mathrm{cA}$ & $0.008 \mathrm{c}$ & $0.006 \mathrm{ab}$ & $0.41 \mathrm{cA}$ & $1.3 \mathrm{a}$ & $6.8 \mathrm{cA}$ & $5.9 \mathrm{cA}$ & $68.0 \mathrm{aB}$ \\
\hline $\begin{array}{l}\text { Acacia } \\
\text { auriculiformis }\end{array}$ & $0.52 \mathrm{aA}$ & $0.017 \mathrm{a}$ & $0.007 \mathrm{a}$ & $2.14 \mathrm{aA}$ & $2.5 \mathrm{a}$ & $8.9 \mathrm{aA}$ & $23.5 \mathrm{aA}$ & $17.1 \mathrm{cB}$ \\
\hline Inga edulis & $0.40 \mathrm{abA}$ & $0.009 \mathrm{bc}$ & $0.006 \mathrm{a}$ & $0.90 \mathrm{bcA}$ & $1.9 \mathrm{a}$ & $7.5 \mathrm{bcA}$ & $12.2 \mathrm{bA}$ & $52.2 \mathrm{bB}$ \\
\hline $\begin{array}{l}\text { Mimosa } \\
\text { caesalpinifolia }\end{array}$ & $0.36 \mathrm{bA}$ & $0.015 \mathrm{ab}$ & $0.004 \mathrm{~b}$ & $1.05 \mathrm{bA}$ & $2.2 \mathrm{a}$ & $8.8 \mathrm{aA}$ & $11.9 \mathrm{bA}$ & $52.2 \mathrm{bB}$ \\
\hline Average & 0.36 & $0.012 \mathrm{~A}$ & $0.006 \mathrm{~B}$ & 1.06 & $2.0 \mathrm{~A}$ & 8.1 & 12.5 & 49.6 \\
\hline & \multicolumn{8}{|c|}{ Camada $0,10-0,20 \mathrm{~m}$} \\
\hline Capoeira & $0.16 \mathrm{abB}$ & $0.007 \mathrm{bc}$ & $0.006 \mathrm{a}$ & $0.30 \mathrm{abB}$ & $1.4 \mathrm{a}$ & $7.8 \mathrm{aB}$ & $3.8 \mathrm{bB}$ & $78.9 \mathrm{aA}$ \\
\hline Pasture & $0.04 \mathrm{bB}$ & $0.004 \mathrm{c}$ & $0.005 \mathrm{ab}$ & $0.16 \mathrm{bA}$ & $1.1 \mathrm{a}$ & $7.2 \mathrm{aA}$ & $2.2 \mathrm{bB}$ & $85.5 \mathrm{aA}$ \\
\hline $\begin{array}{l}\text { Acacia } \\
\text { auriculiformis }\end{array}$ & $0.25 \mathrm{aB}$ & $0.012 \mathrm{a}$ & $0.006 \mathrm{a}$ & $0.79 \mathrm{aB}$ & $1.7 \mathrm{a}$ & $7.4 \mathrm{aB}$ & $10.5 \mathrm{aB}$ & $52.5 \mathrm{bA}$ \\
\hline Inga edulis & $0.25 \mathrm{aB}$ & $0.007 \mathrm{bc}$ & $0.006 \mathrm{a}$ & $0.40 \mathrm{abB}$ & $1.5 \mathrm{a}$ & $7.0 \mathrm{aA}$ & $5.8 \mathrm{abB}$ & $73.0 \mathrm{aA}$ \\
\hline $\begin{array}{l}\text { Mimosa } \\
\text { caesalpinifolia }\end{array}$ & $0.19 \mathrm{abB}$ & $0.011 \mathrm{ab}$ & $0.004 \mathrm{~b}$ & $0.46 \mathrm{abB}$ & $1.7 \mathrm{a}$ & $7.1 \mathrm{aB}$ & $6.4 \mathrm{abB}$ & $73.1 \mathrm{aA}$ \\
\hline Average & 0.18 & $0.008 \mathrm{~B}$ & $0.005 \mathrm{~B}$ & 0.42 & $1.5 \mathrm{~B}$ & 7.3 & 5.8 & 72.6 \\
\hline $\mathrm{CV}(\%)$ & 43.14 & 44.33 & 25.93 & 51.42 & 22.04 & 10.57 & 40.70 & 19.57 \\
\hline
\end{tabular}

For each column (meaning for each soil attribute), means followed by the same uppercase letter (comparing the layers) or the same lowercase letter (comparing the covers) do not differ from each other by the Tukey test at $5 \%$ probability.

As was the case for $\mathrm{C}$, the nitrogen $(\mathrm{N})$ content did not differ between the studied plant covers in the 0.10$0.20 \mathrm{~m}$ layer. However, such differences were verified in the $0-0.10 \mathrm{~m}$ layer. The highest $\mathrm{N}$ content occurred in the capoeira in this superficial layer, which did not statistically differ from Acacia auriculiformis and Mimosa caesalpinifolia, while the lowest content occurred in the pasture, which did not differ from Inga edulis.

Similarly to $\mathrm{C}$, the comparison of the layers revealed that the $\mathrm{N}$ content of the $0-0.10 \mathrm{~m}$ layer was higher compared to 0.10-0.20 m for capoeira, Acacia auriculiformis and Mimosa caesalpinifolia, but not for Inga edulis and pasture.

The differences reported regarding the $\mathrm{C}$ and $\mathrm{N}$ levels in the soil did not lead to significant differences occurring in the $\mathrm{C} / \mathrm{N}$ ratio between the covers and layers studied. The minimum and maximum values (both in the first layer) were 10.7 in the acacia and 14.9 in the pasture, considered low.

The phosphorus content $(\mathrm{P})$ did not differ among the plant covers, but showed a higher average in the superficial 0-0.10 $\mathrm{m}$ layer than in the 0.10-0.20 m layer.

Differences between the plant cover were also verified for $\mathrm{pH}$ (lower mean value in the capoeira and the highest in the acacia, differing from each other) and for the $\mathrm{CEC}_{\mathrm{ef}}$ (with pasture presenting a lower mean value than the others). The means observed for the 0-0.10 m layer for these two attributes were higher than those of the 0.10-0.20 m layer.

Given what is mentioned above in the preceding paragraph, it would be expected that $\mathrm{CEC}_{\mathrm{ef}}$ would have a great dependence on carbon variations and mainly soil $\mathrm{pH}$; however, the obtained correlation coefficients were only regular with the $\mathrm{C}(\mathrm{R}=0.616)$ and weak with the $\mathrm{pH}(\mathrm{R}=0.301)$. This fact should be the narrow ranges of variation verified for both variables, especially for $\mathrm{pH}$. Despite this, it was possible to obtain a model from multiple linear regression analysis which relates $\mathrm{CEC}_{\mathrm{ef}}$ to $\mathrm{pH}$ values and $\mathrm{C}$ content $\left(\mathrm{CEC}_{\mathrm{ef}}=4.4+1.084 \mathrm{pH}+0.113 \mathrm{C}\right)$, in which the coefficients of adjustment, the F-test $(F=27.8)$ and the coefficient of determination $\left(R^{2}=0.494\right)$ were highly significant $(\mathrm{p}<0.01)$, with this model only being valid for the location and conditions for which it was obtained. 
Differently from $\mathrm{CEC}_{\mathrm{ef}}$, there was interaction between the factor's vegetation cover and soil depth for $\mathrm{CEC}_{\mathrm{pH}=7}$. There was no difference between the covers for the 0.10-0.20 m layer, while the highest $\mathrm{CTE}_{\mathrm{pH}=7}$ values for layer 0-0.10 m were in Acacia auriculiformis, Mimosa caesalpiniaefolia and capoeira, in this order, and the smallest in the pasture (the value in Inga edulis was intermediate, not differing statistically from pasture or capoeira). Furthermore, the $\mathrm{CEC}_{\mathrm{pH}=7}$ values from the $0-0.10 \mathrm{~m}$ layer was higher for the Acacia auriculiformis, Mimosa caesalpiniaefolia and capoeira covers compared to those of the $0.10-0.20 \mathrm{~m}$ layer. The layers did not differ for Inga edulis and pasture covers, and both presented the lowest $\mathrm{C}$ levels.

Low base saturation values (value $\mathrm{V}$ ) of the soil were verified in all the studied plots which is also the result of the low $\mathrm{pH}$ values, which in turn causes the negative charges which compose the $\mathrm{CEC}_{\mathrm{pH}=7.0}$ being little occupied by basic cations and predominantly neutralized by $\mathrm{H}+\mathrm{Al}$.

The first two components in the principal component analysis (PCA) were considered, PC1 and PC2, since they can cumulatively retain a sufficient amount of the total information contained in the set of the original variables for each area as defined by 9 variables, which enables its localization with a point on a two-dimensional chart (Table 3).

Table 3: Principal component analysis (PCA) chemical attributes of a Typic Hapludult soil under different vegetation covers in the 0-0.10 m and 0.10-0.20 m layers in Conceição de Macabú, RJ, Brazil.

Tabela 3: Análise de componentes principais (ACP) dos atributos químicos de um Argissolo Vermelho-Amarelo, em Conceição de Macabú, RJ.

\begin{tabular}{|c|c|c|c|c|}
\hline & \multicolumn{2}{|c|}{ Layer 0-0,10 m (Figure 1A) } & \multicolumn{2}{|c|}{ Layer 0,10-0,20 m (Figure 1B) } \\
\hline Variance Component & PC1 & PC2 & PC1 & $\mathrm{PC} 2$ \\
\hline Variables of PCA & \multicolumn{4}{|c|}{ Factor loadings of the main componentes } \\
\hline $\mathrm{pH}$ & 0.921 & -0.029 & 0.804 & -0.547 \\
\hline $\mathrm{C}$ & -0.184 & 0.938 & -0.264 & 0.871 \\
\hline $\mathrm{N}$ & 0.263 & 0.941 & 0.399 & 0.758 \\
\hline $\mathrm{P}$ & -0.040 & -0.570 & 0.925 & 0.369 \\
\hline SB & 0.985 & 0.170 & 0.988 & -0.079 \\
\hline $\mathrm{CEC}_{\mathrm{ef}}$ & 0.834 & 0.450 & 0.899 & 0.339 \\
\hline $\mathrm{CEC}_{\mathrm{pH}=7}$ & 0.566 & 0.807 & -0.023 & 0.482 \\
\hline $\mathrm{V} \%$ & 0.993 & 0.070 & 0.991 & -0.101 \\
\hline $\mathrm{m} \%$ & -0.992 & -0.090 & -0.976 & 0.158 \\
\hline
\end{tabular}

The PCA was performed with the data set of the $0-0.10 \mathrm{~m}$ layer (Figure 1A). The two principal components explained $87.74 \%$ of the total variation between the plant covers, with $54.54 \%$ for the first component (PC1) and 33.20\% for the second component (PC2). In analyzing PC1, it was observed that the variables which most contributed to the total variance of the data were $\mathrm{pH}, \mathrm{SB}, \mathrm{CEC}_{\mathrm{ef}}, \mathrm{V} \%$ and $\mathrm{m} \%$ (Table 3), while $\mathrm{C}, \mathrm{N}$, and $\mathrm{CEC}_{\mathrm{pH}=7}$ were the variables for PC2 (Table 3). The explanation for Figure 2B performed with the data set of the $0.10-0.20 \mathrm{~m}$ layer was $84.55 \%$ and $60.58 \%$ explained by $\mathrm{PC} 1$ and $23.97 \%$ by PC2. The variables which most contributed to the total variation of the data in $\mathrm{PC} 1$ were $\mathrm{pH}, \mathrm{P}, \mathrm{SB}, \mathrm{CEC}_{\mathrm{ef}}, \mathrm{V} \%$ and $\mathrm{m} \%$ (Table 3), while $\mathrm{C}$ and $\mathrm{N}$ were the variables for PC2 (Table 3).
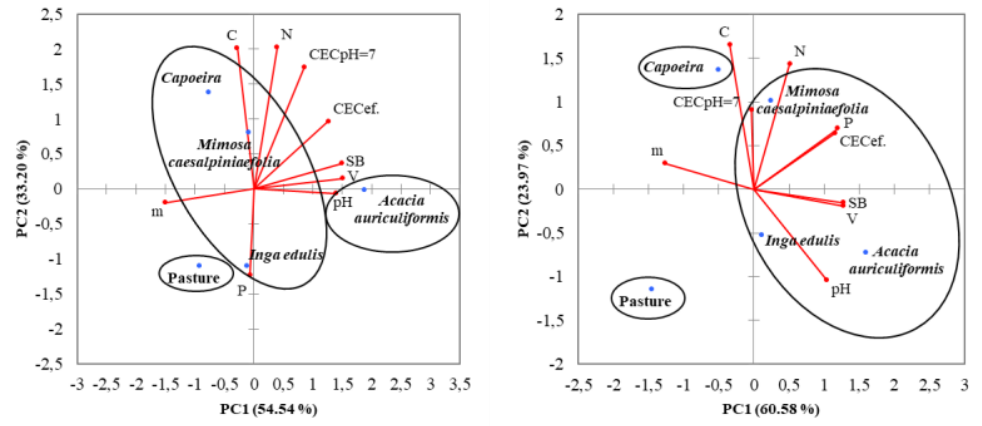

Figura 2: Diagrama de ordenação produzido pela análise de componentes principais (ACP) dos diferentes sistemas de uso da terra e elipses geradas pela análise de agrupamento pelo método de Tocher em função dos atributos químicos. (a) camada 0-0,10 m, (b) camada 0,10-0,20 m.

Figure 2: Ordering diagram produced by principal component analysis (PCA) of the different land use systems and ellipses generated by grouping analysis by the Tocher method in function of the chemical attributes. (A) 0-0.10 m layer, (B) 0.10-0.20 m layer.

FLORESTA, Curitiba, PR, v. 51, n. 2, p. 447-456, abril/jun 2021

Gomes, D. S. et.al.

ISSN eletrônico 1982-4688 
Additionally, the grouping analysis was performed using the Tocher method, and the same PCA clusters (0-0.10 $\mathrm{m}$ and $0.10-0.20 \mathrm{~m})$ were used. In this analysis, it is observed that three groups were formed (Figure 1A), with the first consisting of the area's capoeira, Mimosa caesalpiniaefolia and Inga edulis; the second by Acacia auriculiformis; and the third by pasture. This shows that the Mimosa caesalpiniaefolia and Inga edulis areas were similar to the reference area, even with the Inga edulis area being in the opposite quadrant. The Acacia auriculiformis area proved to be promising for the recovery of the chemical quality of this soil. In addition, it is isolated in a group and is associated with the $\mathrm{SB}, \mathrm{V}$ and $\mathrm{pH}$ variables.

\section{DISCUSSION}

The soil $\mathrm{C}$ content is a direct consequence of the vegetation, and its accumulation in the pasture usually stems from the high density and good distribution of the fasciculated root system of the grasses in the first layers of the soil, as Orgill et al. (2015) stresses. This fact associated with practically absent deposition of plant material on the soil surface in this cover justifies the verified equality regarding the $\mathrm{C}$ levels in the two layers studied. Soil organic matter for capoeira and other arboreal covers mainly stems from litter deposited on the soil surface which leads to differentiation in the C content between the layers (DAWOE et al., 2010).

The chemical attributes of the soil were similar to previous results obtained by several authors in the same area investigated in the present study. Regarding the carbon content in the $0-0.10 \mathrm{~m}$ layer, no differences in soil samples collected about five years after revegetation were identified between the areas preserved under capoeira and pasture and those revegetated under the leguminous Acacia auriculiformis and Mimosa caesalpiniaefolia (ZAIA et al., 2008; COSTA et al., 2014). Moreover, the carbon contents in samples from September 2007 (NUNES et al., 2016) were higher in the capoeira and equivalent between the pasture and the two leguminous species. Rita et al. (2013) found equivalent organic carbon content between leguminous and capoeira and inferior in pasture in samples collected in December 2010 (12 years after revegetation). Thus, the superiority of capoeira in relation to pasture and the presence of leguminous trees in an intermediate position can be observed considering the results cited and also those of the present study, with these (notably the Mimosa caesalpiniaefolia) progressively moving away from the pasture and approaching capoeira.

This predominance of higher $\mathrm{N}$ content in the superficial layer is related to the higher organic carbon contents resulting from litter deposition on the surface of this layer, and can be verified for the data set of the two layers $(\mathrm{N}=60)$, with good correlation between $\mathrm{C}$ and $\mathrm{N}$ variables $(\mathrm{r}=0.741)$, as also observed by Macedo et al. (2008).

In evaluating the potential of nitrogen-fixing pioneer leguminous trees (seven species in consortium, implanted in 1991 with spacing between plants of $2 \mathrm{~m} \times 2 \mathrm{~m}$ ) to recover 1 ha of a severely degraded area on the southern coast Fluminense, Macedo et al. (2008) obtained even more expressive results, verifying that the C (up to $0.20 \mathrm{~m} \mathrm{depth}$ ) and $\mathrm{N}$ (up to $0.30 \mathrm{~m}$ of depth) contents were statistically equal to those of a preserved native forest (Atlantic forest) 13 years after revegetation than the remaining non-recovered area.

In addition to the organic matter content, the soil $\mathrm{N}$ content depends on the type (quality) of organic substrate deposited by the vegetation, highlighting whether or not biological $\mathrm{N}$ fixation occurs. Leguminous trees which fix $\mathrm{N}$ usually increase the organic material and $\mathrm{N}$ contents in the soil when planted (BARRETO et al., 2010; RESENDE, 2013).

The phosphorus content directly relates to the organic matter content, therefore being higher on the surface. Sarmento et al. (2008) also observed higher P and organic matter levels in the superficial layer compared to the deeper layer. Although there were differences in the organic matter content among the plant coverings, these were not sufficient to promote significant differences for the phosphorus variable, which had a high coefficient of variation (88\%). Despite these results, studies conducted by Zaia et al. (2008) and by Rita et al. (2013) in the same area of this study show important differences regarding the nature and availability of the forms of $\mathrm{P}$ present.

The $\mathrm{CEC}_{\mathrm{ef}}$ values were generally very low, with averages varying between 1.1 and $2.5 \mathrm{cmol}_{\mathrm{c}} \mathrm{kg}^{-1}$. This is firstly justified by the fact that the clay fraction of these tropical soils has kaolinitic mineralogy, and usually the presence of sesquioxides of $\mathrm{Fe}$ and $\mathrm{Al}$, both typically low-density negative charges on the surface of the exchange complex (RAIJ, 1969). A second aspect to consider is that given the low availability of charges from the mineral fraction, organic matter assumes a preponderant role for total soil charges (Vezzani et al., 2008); however, in the present case its presence is not as expressive with the $\mathrm{C}$ content between 10 and $20 \mathrm{~g} \mathrm{~kg}^{-1}$. Finally, the most relevant justification for the low $\mathrm{CEC}_{\mathrm{ef}}$ values found is the fact that the ionization of the negative charges arising from the clays and mainly of the organic matter is highly dependent on the elevation of the $\mathrm{pH}$, which in the present case is very low (less than 4.5), already approaching the so-called zero charge point.

The differences of $\mathrm{CEC}_{\mathrm{pH}=7}$ cited (or its absence) are associated with variations in soil $\mathrm{C}$ content, since organic matter not only promotes the increase of $\mathrm{CEC}_{\mathrm{pH}=7}$, but is also responsible for most of the negative charges

FLORESTA, Curitiba, PR, v. 51, n. 2, p. 447-456, abril/jun 2021.

Gomes, D. S. et.al.

ISSN eletrônico 1982-4688

DOI: $10.5380 /$ rf.v51 i2. 69591 
generated in tropical soils (RAIJ, 1969; VEZZANI et al., 2008). Thus, in the present case it was possible to obtain a good correlation coefficient between the aforementioned variables $(\mathrm{R}=0.703)$, which could have been better if the variation range of $\mathrm{C}$ content was wider.

In the same study cited above, Araújo et al. (2007) verified that the behavior of $\mathrm{CEC}_{\mathrm{pH}=7}$ was similar to that of organic matter, with values in the superficial layer $(0-0.05 \mathrm{~m})$ of the soil under Cerrado vegetation equivalent to the soil under natural pasture and above the soil under cultivated pasture, Pinus forest and conventional cultivation.

Despite the acid reaction of the soil $(\mathrm{pH}<4.5)$, the $\mathrm{Al}$ levels were not very high (around $\left.1 \mathrm{cmol}_{\mathrm{c}} \mathrm{kg}^{-1}\right)$. Still, they were low enough for the alic character to occur (value $M>50 \%$ ) in all covers and soil layers (with the exception of $0-0.10 \mathrm{~m}$ of acacia), which is a consequence of the low chemical activity of soil colloids (i.e. low $\mathrm{CEC}_{\mathrm{ef}}$ values and even $\mathrm{CEC}_{\mathrm{pH}=7}$ ). Thus, any statistical differences between the layers and the plant cover are not relevant.

In view of the low $\mathrm{pH}$ values, most of the charges which compose the $\mathrm{CEC}_{\mathrm{pH}=7}$ correspond to $\mathrm{H}+\mathrm{Al}$ (or potential acidity), so that the values of this sum and differences between plant covers and depths are very similar to that already discussed for the $\mathrm{CEC}_{\mathrm{pH}=7}$.

The remainder of the exchange complex charges $\left(\mathrm{CEC}_{\mathrm{pH}=7}\right)$ are occupied by the basic cations $(\mathrm{Ca}, \mathrm{Mg}, \mathrm{K}$ and $\mathrm{Na}$ ), totalized by the sum of bases, and for which low levels were verified (Table 2). Similar to what was discussed for $\mathrm{Al}$, possible statistical differences between the layers and the plant cover as to the content of these nutrients and the SB become little relevant and is intimately associated with soil organic matter, the main source of negative soil charges (RAIJ, 1969; VEZZANI et al., 2008) which maintains these nutrients retained in the exchange complex.

The present study confirmed the trends indicated in previous studies conducted in the same area regarding the chemical attributes of the soil (GAMA-RODRIGUES et al., 2008; ZAIA et al., 2008; RITA et al., 2013, MANHÃES et al., 2013; COSTA et al., 2014; NUNES et al., 2016). These alterations occurred in order to make the soil of the revegetated areas closer to the soil under capoeira and more distinct of the soil under pasture, both in aspects considered negative, such as the decrease of the soil $\mathrm{pH}$, and positive, such as the elevation of $\mathrm{C}$ and $\mathrm{N}$ levels and of $\mathrm{CEC}_{\mathrm{pH}=7.0 \text {. }}$

Another relevant modification (whose negative or positive side is certainly circumstantial) is regarding the greater stratification between the superficial and subsurface layers for several chemical attributes evaluated such as the $\mathrm{C}$ content, the quantity of charges in natural $\mathrm{pH}$ exchange complex $\left(\mathrm{CEC}_{\mathrm{ef}}\right)$ or buffered $\left(\mathrm{CEC}_{\mathrm{pH}=7.0}\right)$, the macronutrient contents studied $(\mathrm{N}, \mathrm{P}, \mathrm{Ca}, \mathrm{Mg}$ and $\mathrm{K}$ ), and the sum of bases value. This approximation is evidenced by the PCA and Tocher method analysis, in which it is verified that the revegetated areas are now in the same quadrant of capoeira and composing the same group by Tocher, and also in the case of the $0.10-0.20 \mathrm{~m}$ layer. The revegetated areas are in an intermediate position between the reference area (capoeira) and the degraded area (pasture).

In studying the soil in these areas in samples collected in the $0-0.10 \mathrm{~m}$ soil layer at 2 years and 8 months after its implantation, Gama-Rodrigues et al. (2008) verified (through the Tocher method) that areas were distributed in two groups, such that when $\mathrm{C}, \mathrm{N}$ and microbial attributes were used, the first group was formed by acacia, Mimosa caesalpiniaefolia, eucalyptus and capoeira, and the second by pasture, but when only chemical attributes $\left(\mathrm{pH}, \mathrm{Al}^{3+}, \mathrm{P}\right.$ e SB) were used the first group was formed by acacia, Mimosa caesalpiniaefolia, eucalyptus and pasture, and the second by capoeira. This result reveals the dynamics of SOM transformation over the years, as the pasture area remains in an individual group, but the revegetated areas are associated with the forest (Figure 1A) or in an intermediate group (Figure 1B). tThus, wha can be said is that the chemical recovery of the soil is slow and is under greater influence in the topmost soil layer, but there is a tendency for improvement also in layers below.

It is also worth noting that it is possible (and perhaps probable) that such modifications are still underway, and may be confirmed in a more consistent manner in any subsequent assessments. In moderately degraded areas, edaphic benefits of revegetation may not appear in the short term (few years), but they are usually observed in medium and long term (in a few decades) (FONTES et al., 2014).

These grouping differences are therefore the result of the differences in the attributes observed as a function of management, enabling a more widespread analysis of the quality of the studied areas. A probable explanation for this result is due to the fact that the pasture area promotes depreciation of the OM as a function of grazing, which in turn causes low soil cover, leaving them exposed to climate actions.

\section{CONCLUSIONS}

FLORESTA, Curitiba, PR, v. 51, n. 2, p. 447-456, abril/jun 2021

Gomes, D. S. et.al.

ISSN eletrônico 1982-4688

DOI: $10.5380 /$ rf.v51 i2. 69591 
- The soil of the study area under the five vegetation covers and in the two evaluated layers presented low chemical quality from the agronomic point of view, with low $\mathrm{pH}$ values, effective CEC, nutrient content and base saturation.

- The chemical quality in the soil under capoeira of the 0-0.10 m layer was higher than that of $0.10-0.20 \mathrm{~m}$, with the highest $\mathrm{C}$ content, higher amount of charges in the exchange complex, higher nutrient content and greater sum of bases in the superficial layer as a consequence of the deposition of a litter layer on the soil.

- The chemical quality in the soil under pasture of the $0-0.10 \mathrm{~m}$ layer was equivalent to that of $0.10-0.20 \mathrm{~m}$, with the values of the attributes studied equal between the layers. This could be attributed to the negligible deposition of organic material on surface and the uniformly distributed fasciculated grass root system in these layers.

- The set of chemical variables used were sensitive to explain the similarity and/or dissimilarity resulting from the vegetation cover and the evaluated layers.

\section{REFERENCES}

ANDERSON, J. D.; INGRAM, J. S. I. Tropical soil biology and fertility: A handbook of methods. 2.ed. Wallingford, CAB International. 1993. 221p.

ARAÚJO, R.; GOEDERT, W. J.; LACERDA M. P. C. Quality of a soil under different uses and under native Cerrado. Brazilian Journal of Soil Science, v.31, n.5, p.1099-1108. 2007.

BARRETO, P. A. B.; GAMA-RODRIGUES, E. F.; GAMA-RODRIGUES, A. C.; BARROS, N. F.; ALVES, B. J. R.; FONSECA, S. Mineralização de nitrogênio e carbono em solos sob plantações de eucalipto, em uma sequência de idades. Revista Brasileira de Ciência do Solo, v.34, n.3, p.735-745, 2010.

BONINI, C. S. B.; ALVES, M. C.; MONTANARI, R. Lodo de esgoto e adubação mineral na recuperação de atributos químicos de solo degradado. Revista Brasileira de Engenharia Agrícola e Ambiental, v.19, p.388$393,2015$.

CUNHA NETO, F. V.; PEREIRA, M. G.; LELES, P. S. S.; ABEL, E. L. S. Atributos químicos e físicos do solo em áreas sob diferentes coberturas florestais e pastagem em Além Paraíba - MG. Ciência Florestal, v. 28, p. 1324. 2018.

COSTA, M. G.; GAMA-RODRIGUES, A. C.; ZAIA, F. C.; GAMA-RODRIGUES, E.F. Leguminous arboreal for recovery of degraded areas with pasture in Conceição de Macabu, Rio de Janeiro, Brazil. Scientia Forestalis, v.42, p.101-112. 2014.

DAWOE, E.K.; ISAAC, M. E.; EUASHIE-SAM, J. Litterfall and litter nutrient dynamics under cocoa ecosystems in lowland humid Ghana. Plant Soil, v. 330, p.55-64, 2010.

EMBRAPA - Empresa Brasileira de Pesquisa Agropecuária - National Center for Soil Research. Manual and Methods of soil analysis. 3. ed. Brasília, Embrapa, 2017. 573p.

FAUSTINO, L. L.; MARCIANO, C. R.; ALVES, M. C. Morphometry and size distribution of aggregates from a Typic Hapludult soil under natural secondary forest, implanted leguminous trees and degraded pasture in the Atlantic coast of Brazil. Geoderma Regional, v. 23, p. e00350, 2020.

FONTES, A.; GAMA-RODRIGUES, A. C.; GAMA-RODRIGUES, E. F.; SALES, M. V. S.; COSTA, M. G.; MACHADO, R. C. R. Nutrient stocks in litterfall and litter in cocoa agroforests in Brazil. Plant Soil, v. 383, p.313-335, 2014.

GAMA-RODRIGUES, E. F.; GAMA-RODRIGUES, A. C.; PAUlinO, G. M.; FRANCO, A. A. Chemical and Microbiological Attributes of Soils under Different Vegetation Covers in the North of the State of Rio de Janeiro. Brazilian Journal of Soil Science, v.32, n.4, p.1521-1530. 2008.

GOMES, D. S.; MARCIANO, C. R. FAUSTINO, L. L. Physical quality of a Typic Hapludult soil under forest leguminous trees and pasture. Floresta e Ambiente, v.25, n.4, e20170400, 2018.

MACEDO, M. O.; RESENDE, A. S.; GARCIA, P. C.; BODDEY, R. M.; JANTALIA, C. P.; URQUIAGA, S.; CAMPELLO, E. F. C.; FRANCO, A. A. Changes in soil C And N stocks and nutrient dynamics 13 years after recovery of degraded land using leguminous nitrogen-fixing trees. Forest Ecology Management, v.255, n.5-6, p.1516-1524. 2008.

FLORESTA, Curitiba, PR, v. 51, n. 2, p. 447-456, abril/jun 2021

Gomes, D. S. et.al.

ISSN eletrônico 1982-4688 
MANHÃES, C. M. C.; GAMA-RODRIGUES, E. F.; MOÇO, M. K. S.; GAMA-RODRIGUES, A.C. Meso and macrofauna in the soil and litter of leguminous trees in a degraded pasture in Brazil. Agroforestry Systems, v.87, n.5, p.993-1004. 2013.

MEURER, E. J. Factors Influencing plant growth and development. In: NOVAES, R. F.; ALVAREZ, V. H.; BARROS, N. F.; FONTES, R. L. F.; CANTARUTTI, R. B.; NEVES, J. C. L. (eds.) Soil Fertility. Viçosa, Brazilian Society of Soil Science, p.375-470. 2007.

NUNES, D. A. D.; GAMA-RODRIGUES; E. F.; BARRETO, P. A. B.; GAMA-RODRIGUES, A. C.; MONROE, P. H. M. Carbon and nitrogen mineralization in soil of leguminous trees in a degraded pasture in northern Rio de Janeiro, Brazil. Journal of Forestry Research. v.27, p.91-99. 2016.

ORGILL, S. E.; SPOLJARIC, N.; KELLY, G. Soil carbon under perennial pastures; benchmarking the influence of pasture age and management. IOP Conf. Series: Earth and Environmental Science, v.25, p.1-4 2015.

RAIJ, B. V. The ability to exchange cations of organic and mineral fractions in soils. Bragantia, v.28, p.85-112. 1969.

RESENDE, A. S. Uso de leguminosas arbóreas na recuperação de áreas degradadas. Tópicos em Ciências do Solo. p. 71-92. 2013.

RITA, J. C. O.; GAMA-RODRIGUES, A. C.; GAMA-RODRIGUES, E. F.; ZAIA, F. C.; NUNES, D. A. D. Mineralization of organic phosphorus in soil size fractions under different vegetation covers in the north of Rio de Janeiro. Revista Brasileira de Ciência do Solo, 37:1207-1215. 2013.

SANTOS, H.G. dos; JACOMINE, P.K.T.; ANJOS, L.H.C. dos; OLIVEIRA, V.Á. de; LUMBRERAS, J.F.; COELHO, M.R.; ALMEIDA, J.A. de; ARAÚJO FILHO, J.C. de; OLIVEIRA, J.B. de; CUNHA, T.J.F. Sistema brasileiro de classificação de solos. 5.ed. rev. e ampl. Brasília: Embrapa, 2018. 356p. Available at: <https://ainfo.cnptia.embrapa.br/digital/bitstream/item/199517/1/SiBCS-2018-ISBN-9788570358004.pdf>. ccessed on: May 222020.

SARMENTO, P.; RODRIGUES, L. R. A.; CRUZ, M. C. P. Chemical and physical Attributes of an Argissol cultivated with Panicum maximum Jacq. cv. IPR-86 Milênio, Under rotational stocking, and fertilized with nitrogen. Brazilian Journal of Soil Science, vol.32 no.1 2008.

VEZZANI, F. M.; CONCEIÇÃO, P. C.; MELLO, N. A.; DIECKOW, J. Organic Matter and soil quality. In: SANTOS, G. A.; SILVA, L. S.; CANELLAS, L. P.; CAMARGO, F. A. (eds.) Fundamentals of soil organic matter: tropical and subtropical Ecosystems. 2. ed. Porto Alegre, Metropolis. p.483-494. 2008.

ZAIA, F. C.; GAMA-RODRIGUES, A. C.; GAMA-RODRIGUES, E. F. Forms of phosphorus in the soil under forest legumes, secondary forest and pasture in the North Fluminense. Brazilian Journal of Soil Science, 32:11911197. 2008.

FLORESTA, Curitiba, PR, v. 51, n. 2, p. 447-456, abril/jun 2021. 